\title{
A study on mediating effect of institute reputation on relationship between institute social re- sponsibility and student loyalty: Exploring concerns in Pakistani private HEIs
}

\author{
Muhammad Azeema ${ }^{a}$ Che Azlan Bin Taib ${ }^{b^{*}}$ and Halim Mad Lazim ${ }^{b}$
}

${ }^{a}$ PhD Candidate, School of Technology Management and Logistics, Universiti Utara Malaysia, Malaysia ${ }^{b}$ Associate professor, School of Technology Management and Logistics, Universiti Utara Malaysia, Malaysia

\section{H R O N I C L E}

\section{Article history:}

Received: June 1, 2019

Received in revised format: June

222019

Accepted: June 27, 2019

Available online:

June 27, 2019

Keywords:

Institute Social Responsibility

Institutes Reputation

Student Loyalty

HEIS \begin{abstract}
A B S T R A C T
The aim of this study is to determine the mediating role of the institute reputation between institute social responsibility and student loyalty. The present study uses a multi-stage sampling technique, which first creates four clusters; including Karachi, Quetta, Peshawar, and Lahore, and picks one cluster; namely Lahore, randomly for the purpose of the study. Second, proportionate sampling technique is used to calculate the proportionate values of every individual educational institute. Finally, systematic sampling is used to compute the sampling interval $\mathrm{k}^{\text {th }}$ number of individual universities. Data are collected from the provincial capital city of Punjab province (Lahore) and a total of 511 questionnaires are distributed among postgraduate students under business education discipline of private HEIs, 206 questionnaires are excluded from the sample due to some missing and misleading values, and final analysis is run by using SmartPLS 3.2.8 on 345 questionnaires. Findings elucidate that institutes social responsibility did not have any direct relationship with student loyalty. However, institute social responsibility has indirect relationship with student loyalty thru the mediating variable of institute reputation. Institute reputation also has a significant and positive influence on student loyalty.
\end{abstract}

\section{Introduction}

Nowadays, Higher Education (HE) has entered in the marketplace and the universities administrators are experimenting by deploying the improved strategies for maintaining student's enrollments (Hossler et al., 2009). The higher educational institutes (HEIs) started to adopt the models as well as practices from the business community from 1980s to 1990 s, and the academia saw the starting stage of the marketing as a tool used for recruitment purpose (Gibbs \& Knapp, 2012). The major reason on why adopting the business practice to the HEIs has varied the degree of success in the field of academia is the inspiration when universities considered their students like customers in a traditional business sense, academic quality, pedagogical objectives, and the rigor of the academic programs might endure (Lange, 2016). Literature reveals that this type of business existed in some accepted models of educational institutes in the

\footnotetext{
* Corresponding author. Tel.: +60107629624

E-mail address: c.azlan@uum.edu.my (C.A.B. Taib) 
community and the students were considered as customers for the institutions (Hennig-Thurau et al., 2001).

HEIs also start to focus on institutional reputation (Nguyen \& LeBlanc, 2001). In other words, the increase in competition within institutions has created much attention towards the service quality of the HEIs (Yeo \& Marquardt, 2011). This competition among several institutes and marketplace customer awareness facilitates institutions to attain their particular goals (Ipate \& Parvu, 2011). Helen (2011) recognized that establishing customer relationship is vital for a business to attain a sustained competitive advantage. Literature found that establishing a strong relationship with customers is the most important for the education sector particularly the private institutes where a significant relationship between students and HEIs might decrease the potential for high attrition and enhance the student retention rate that ultimately enhances student loyalty (Moore \& Bowden-Everson, 2012). Some of the studies demonstrate that service quality was recognized by the outcome of comparison customer perceptions and expectations regarding the way that services were performed (Caruana, 2002; Parasuraman et al., 1985). Meanwhile, the term institute or corporate reputation is generally called firms characteristics (Liengjindathaworn et al., 2015). Some researchers recommend that academic programs and the higher educational institution's reputation in the marketplace had a significant influence on students to join particular institute (Berger \& Wallingford, 1997; Sevier, 1994). Institute social responsibility plays a significant role in determining student loyalty. Moreover, institute social responsibility has in the top of the list of the tasks for higher educational institutes and this variable is significance for institutions (Amiri et al., 2015). Hence, the institute social responsibility of the HEIs has to be careful not to divert from their major mission to ensure and provide the students with an opportunity to become an educated professionals. Moreover, the institute social responsibility has another object such as to take care of all the rights of stakeholders of educational institutes. A study investigated the relationship between reputation and the loyalty supported each other but additionally examined the relationship between service quality and the social activities were not significant with the customer loyalty with the help of corporate reputation as a mediating variable (Helgesen, 2008). The literature demonstrates that loyalty is divided into two dimensions including attitudinal loyalty and behavioral loyalty (Anderson \& Srinivasan, 2003; Balabanis et al., 2006; Ribbink et al., 2004). Hence, the current research attempts to determine the mediating effect of institute's reputation between institutes social responsibility and student loyalty.

This study used two theories to develop a theoretical framework such as signaling theory and strategic enrollment management theory. The signaling theory was formulated to explain the relationship between educations and the earnings explained by the education signaling function to the employer (Stiglitz, 1975). Institute social responsibility is a key element in perspective of signaling theory that takes the attention of the customers by providing a signal for an institute norm, codes, business standards, ethics, and values (Turban \& Greening, 1997). Hence, the appropriate disclosure of the institutes regarding good deeds in a part of the institute's social responsibility that significantly enhances customers/students loyalty (Chatman, 1989). According to Dolence (1993), the factors that change the decisions of the students to attend institute or continue their further studies linked with enrolments yield a fair game. Donald Hossler and Kalsbeek (2013) stated that the strategic enrolment management is not only a process but also a research-dependent process, data-driven, and every successful enrolment management organization has well-managed resources to support institutional research. Moreover, the strategic enrolment management technique is used to maintain as well as to attain maximize the enrolment and by managing the institute's resources to improve institute revenues (McNay, 2017).

\section{Literature review and hypotheses development}

\subsection{Student Loyalty}

The students' loyalty towards their institute is similar to the customers' loyalty towards a specific service or product (Fatima \& Khero, 2019). The term loyalty can keep up by continuously involving the exstudents into current events, arranging alumni dinners. Moreover, the loyal students playing a significant 
role for institutions and is considered a source of positive word-of-mouth for institutions (Fatima \& Khero, 2019). In addition, loyal students suggest new students join that particular institute. According to Fisher (2001) students who are involved in the extra activities promote a good image of their particular institutions. Most familiar definition of loyalty is presented by Oliver (1999) who portrayed loyalty as a deeply held commitment to re-buy ideal goods or services consistently in the future, regardless of situational influences and the marketing efforts having the potential to cause switching the behavior.

Student loyalty is a crucial element for the success of institutions (Nyadzayo \& Khajehzadeh, 2016). The term loyalty is a feeling of attachment to the services or goods that has a significant direct influence on the behavior of consumer/student behavior (Jones, 1995). Loyal consumers towards brand tend to purchase again that points towards behavioral loyalty (Ram \& Wu, 2016). Truly loyal consumers with brands not only re-purchase similar brands but also hold a positive attitude towards product, brand, or services (Ali et al., 2018). Hence, the term loyalty is divided into two dimensions including behavioral loyalty and attitudinal loyalty (Jacoby \& Kyner, 1973).

\subsection{Institute social responsibility}

Universities have an opportunity to squeeze the concerns of their particular stakeholders including students and the business supporters and to lead in responding in the realm of practicing and communicating corporate social responsibility (CSR) (Goosen, 2009; Youness, 2012). HEIs recognize that it is a competitive marketing term of creating an ongoing stream of satisfied alumni, attracting new students and addressing the concerns of business supporters, a strategy which incorporates CSR.

The judgment tool objects to inspect the degree to the university about corporate social responsibility in the whole world. Indeed, the university website makes sure the transparency about institutes social responsibility practices that is a situation of main accrediting institutes that contributes to keeping stakeholders aware as well as update (Youness, 2012). It mainly focuses on providing equal opportunities in the disciplinary actions, recruitment, admission, employment, evaluation, and the advancement for the route of diversity. However, in Pakistan HEIs have not had a focus on these activities on how institutions in Pakistan attract national as well as international students for their new enrollments because in Pakistan and other countries HEIs are running in a highly competitive environment. According to Majeed et al. (2015) institutes social responsibility can minimize this gap on emphasizing onto the perceptions, expectations, and the student's awareness. Baker (2005) explains the social responsibility reflection towards societal expectations of business behavior as the stakeholders to be expected by morally and socially required and demand of business. Few studies investigate the relationship between corporate social responsibility and customer loyalty. Findings reveal that corporate social responsibility significantly enhances customer's loyalty (Cha et al., 2016; Choi \& La, 2013; Shin \& Thai, 2015). Despite this, few of the studies have revealed that corporate social responsibility had mixed results with customer loyalty (Cha et al., 2016; Tingchi Liu et al., 2014). Hence, there is a need for a mediating variable that explains this relationship well. In this study, institutes reputation is used as a mediating variable.

Institute reputation is something intangible that attracts the stakeholders to a particular institute (Fombrun et al., 2004). Institutes reputation is one of the significant factors that move with corporate social responsibility (Fombrun \& Shanley, 1990). Moreover, the suppliers, customers, and society normally try to be associated with the institutes or organizations with good corporate social responsibility record. Therefore, the cumulative effect of corporate social responsibility leads to a good institute's reputation. However, few of the studies conclude that institutes/corporate social responsibility significantly enhance corporate/institute reputation (Baraibar-Diez \& Sotorrío, 2018; Benitez et al., 2017; Den Hond et al., 2014). Followings are the proposed hypotheses:

H1: There is a significant and positive relationship between institute social responsibility and student loyalty. 
H2: There is a significant and positive relationship between institute social responsibility and institute reputation.

H3: Institute reputations significantly mediate between institutes social responsibility and student loyalty.

\subsection{Institute reputation}

Institutes' reputation is associated with the perceptual depiction of an institute past, present, and future prospects which defines the institute general appeal to their stakeholders (Fombrun, 1996). Literature views institute or corporate reputation as a socially shared feeling and consequences regarding how well an organization will behave in any particular circumstances (Bromley, 2002; Sandberg, 2002). Generally, reputation depends on the organizations success to address its stakeholders' demands to meet their expectations (Mukasa et al., 2015). Moreover, corporate reputation plays a significant role in enhancing the customer's loyalty (Ali \& Zia, 2011). Literature elucidates that corporate reputation is considered as one of the main elements that significantly influences customer satisfaction and ultimately enhances the customers' loyalty (Nuraryo et al., 2018). Therefore we consider the following hypothesis:

$\mathbf{H}_{4}$ : There is a significant and positive relationship between institute reputation and student loyalty.

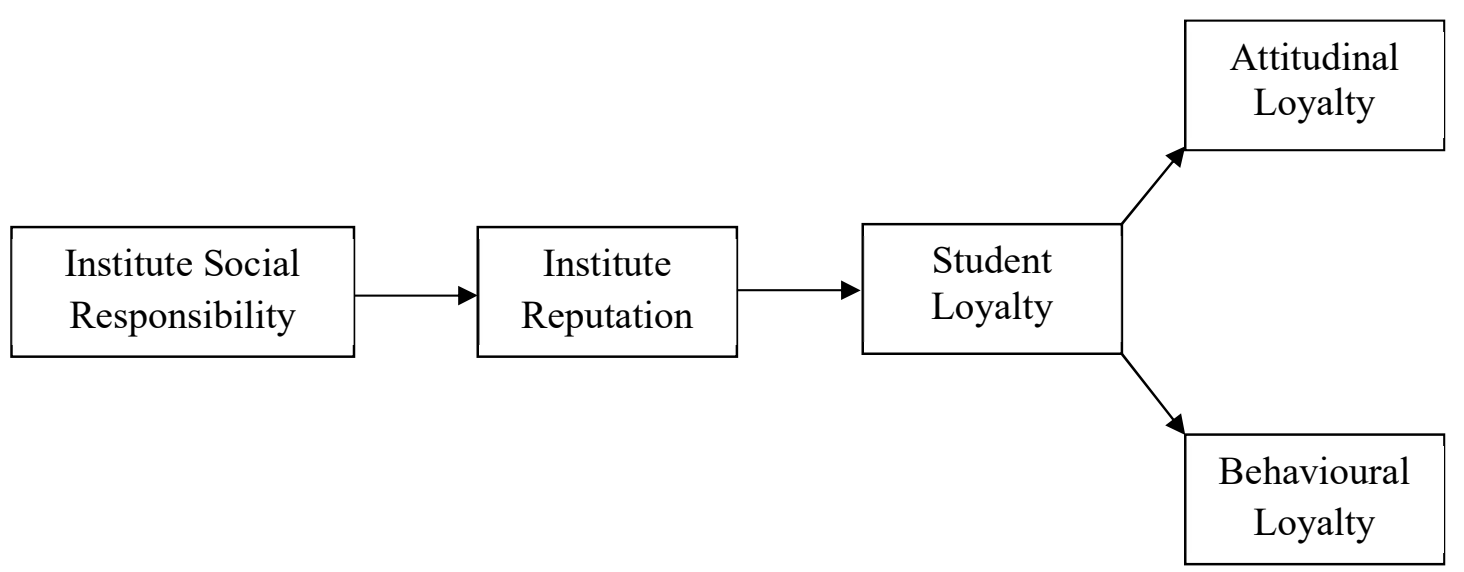

Fig. 1. Theoretical Framework

\section{Research methodology}

This section plays a significant role to determine the objectives of that research (Rehman et al., 2019). In addition, researchers conclude that there is a need of a suitable technique in attaining desired objectives and researchers also try to answer the theoretical and practical problem (Rehman et al., 2019). This research is quantitative and co-relational in nature and questionnaires are used to collect the necessary data from the respondents.

\subsection{Questionnaire development}

The theoretical framework of this research contains three variables and every variable is measured by using some items. Particularly, every item of the construct is measured with the help of five-Likert scale ( 5 for strongly agree and 1 for strongly disagree). Institute social responsibility consists of 7 items and these items are adapted from the literature (Helm, 2005; Turker, 2009; Skudiene \& Auruskeviciene, 2012); institute reputation consists of 7 items and these items adapted from othe studies (Ali et al., 2016; Clemes et al., 2013; Dehghan et al., 2014); and student loyalty consists of 17 items and these items adapted from other studies (Annamdevula \& Bellamkonda, 2016; Jaiswal \& Lemmink, 2017; Casidy \& Wymer, 2016; Heo \& Lee, 2016).

3.2. Population, sampling, and sample size 
The current research is based on the private HEIs in the provincial capital city (Lahore) of Punjab province, Pakistan. The selection of private universities in the present study due to the low number of enrolments e.g. the total population of private HEIs is only the $17 \%$ of the whole population of public HEIs. Moreover, private universities are not funded by the government and do not get any benefit from HEC, whereas private educational institutions put more efforts to survive in the competitive marketplace that's why researchers select private HEIs for the present study. All private HEIs under the business education discipline were selected for data collection in the region of Punjab province (Lahore) in Pakistan, for the reason that it is quite difficult to collect data from the whole private HEIs of Pakistan. The main focus of the current study is postgraduate students (Master, MS/MPhil, and $\mathrm{PhD}$ ) studying in a business education discipline because the postgraduate students are considered more mature than the undergraduate students (Fung et al., 2017). 7,511 students were selected for data collection from eleven private HEIs.

The present study used a multi-stage sampling technique for data collection. First, cluster sampling technique used to make four clusters (Karachi, Quetta, Lahore, and Peshawar) was considered for the four provincial capital cities of all four provinces of Pakistan, hereafter we select one cluster randomly. The randomly selected cluster was the provincial city of Punjab province (Lahore) out of the four clusters. Accordingly, Abubakar and Mokhtar (2015) observed the characteristics as per the universities and assured that cluster sampling design was found homogeneity across groups e.g. (Pakistani university student) and heterogeneity within the group e.g. (HEIs student from diverse social, religious, and ethnic background). Though, Hair et al. (2007) further confirmed that cluster sampling method is suitable due to diverse student's groups are appropriately represented in the sample size of 551.

Second, proportionate sampling technique was used to compute the proportionate values of the population of every individual university. Finally, systematic sampling was used to compute the sampling interval $\mathrm{k}^{\text {th }}$ number of individual university which was almost (13) $\mathrm{k}^{\text {th }}$ number of individual university. This study used Krejcie and Morgan (1970) table for the selection of sample size and 367 sample size was selected because the population of this study was 7,511. We increased the sample size by $50 \%$ as per the recommendation of Salkind (2012). Hence, the sample of this study reached to 551. A sample size of this research included 551 students from all 11 universities. The self-administered approach was followed for data collection of desired respondents. Out of 551 questionnaires, only 345 questionnaires were used for the final analysis and the remaining 206 questionnaires were excluded from the sample because these questionnaires had some misleading values. The response rate of this study was $62.61 \%$ that is acceptable.

\subsection{Data Analysis}

The study used SmartPLS 3.2.8 to determine the theoretical model because SmartPLS is the $2^{\text {nd }}$ generation technique as recommended by Hair et al. (2014). The reason behind this to use SmartPLS 3.0 is that this tool is best to handle both simple and complex theoretical models (Hair et al., 2014). Moreover, few prior researchers conclude that PLS-SEM provides better results as compared to the covariance-based approach (Afthanorhan, 2013; Hair et al., 2014). PLS-SEM includes two models like the measurement model (outer model) and the structural model (inner model). This study used both.

\subsubsection{Measurement model}

This study calculates the measurement model by using three things such as content validity, convergent validity, and Discriminant validity as suggested (Hair et al., 2014).

\subsubsection{Content Validity}

Content validity means a situation where the items of a particular construct measured demonstrate the higher loadings on their own construct than other constructs in the theoretical model (Rehman et al., 
2019). Few prior studies suggested the content validity measure with the help of cross-loadings (Chin, 1998b; Hair et al., 2010). Table 1 illustrates that this study fulfills the above-mentioned criteria.

\section{Table 1}

Cross loadings

\begin{tabular}{|c|c|c|c|c|}
\hline Variable & Items & ISR & IR & SL \\
\hline \multirow{7}{*}{ Institute social responsibility (ISR) } & ISR1 & 0.765 & 0.461 & 0.385 \\
\hline & ISR2 & 0.832 & 0.538 & 0.450 \\
\hline & ISR3 & 0.829 & 0.574 & 0.426 \\
\hline & ISR4 & 0.867 & 0.594 & 0.478 \\
\hline & ISR5 & 0.843 & 0.549 & 0.418 \\
\hline & ISR6 & 0.830 & 0.576 & 0.466 \\
\hline & ISR7 & 0.804 & 0.595 & 0.480 \\
\hline \multirow[t]{7}{*}{ Institute reputations (IR) } & IR1 & 0.584 & 0.817 & 0.552 \\
\hline & IR2 & 0.496 & 0.795 & 0.546 \\
\hline & IR3 & 0.568 & 0.848 & 0.589 \\
\hline & IR4 & 0.537 & 0.797 & 0.534 \\
\hline & IR5 & 0.514 & 0.781 & 0.498 \\
\hline & IR6 & 0.537 & 0.761 & 0.497 \\
\hline & IR7 & 0.549 & 0.805 & 0.550 \\
\hline \multirow[t]{17}{*}{ Student loyalty (SL) } & AL1 & 0.350 & 0.462 & 0.781 \\
\hline & AL2 & 0.399 & 0.522 & 0.831 \\
\hline & AL3 & 0.438 & 0.527 & 0.863 \\
\hline & AL4 & 0.419 & 0.494 & 0.853 \\
\hline & AL5 & 0.387 & 0.445 & 0.840 \\
\hline & AL6 & 0.418 & 0.483 & 0.831 \\
\hline & AL7 & 0.422 & 0.405 & 0.697 \\
\hline & AL8 & 0.488 & 0.437 & 0.660 \\
\hline & BL1 & 0.439 & 0.487 & 0.793 \\
\hline & BL2 & 0.368 & 0.515 & 0.833 \\
\hline & BL3 & 0.344 & 0.459 & 0.760 \\
\hline & BL4 & 0.229 & 0.411 & 0.667 \\
\hline & BL5 & 0.369 & 0.436 & 0.719 \\
\hline & BL6 & 0.290 & 0.424 & 0.630 \\
\hline & BL7 & 0.415 & 0.543 & 0.799 \\
\hline & BL8 & 0.422 & 0.538 & 0.819 \\
\hline & BL9 & 0.448 & 0.566 & 0.805 \\
\hline
\end{tabular}

\subsubsection{Convergent Validity}

According to Rehman et al. (2019) convergent validity refers to the degree to see that all items of particular variable measure the variables. Convergent validity includes three major things like factors loadings, average variance extracted (AVE), and the composite reliability (CR) (Hair et al., 2013).

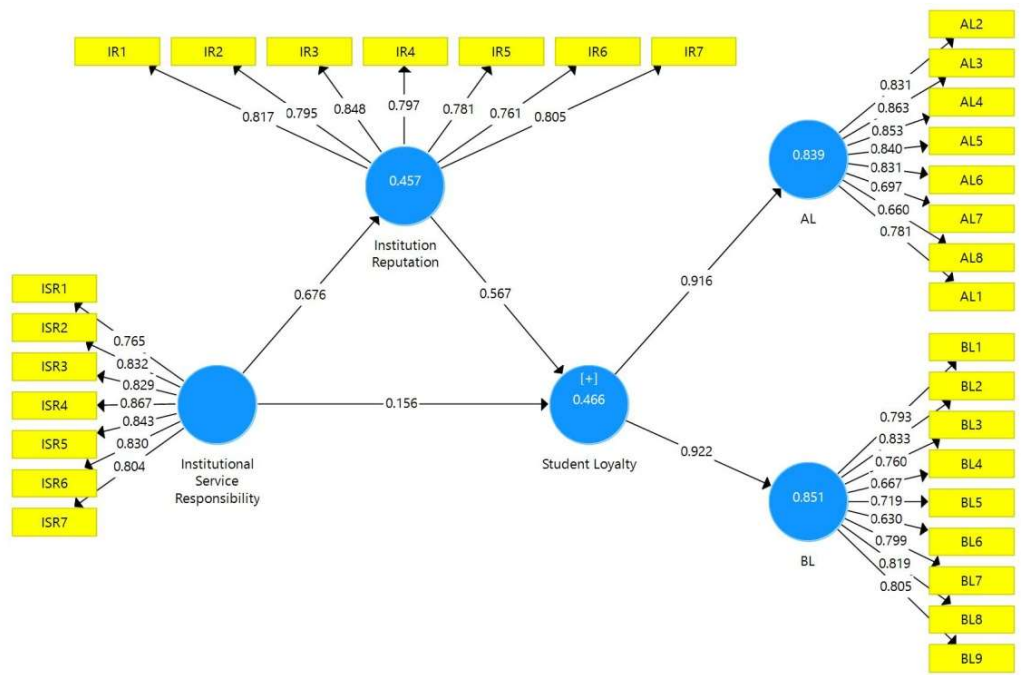

Fig. 2. Measurement Model 
Researchers reveal that the value of factors loading, AVE should be greater than $0.50,0.50$, and 0.70 , respectively (Hair Jr et al., 2013). Hayduk and Littvay (2012) conclude to delete all those items that have factors loadings below 0.50 to get better results of CR and AVE. Cronbach's alpha should be higher than 0.60 (Nunnally, 1978). Fig. 2 demonstrates the measurement model that includes the institute's social responsibility, the institute's reputation, and student loyalty. Table 2 depicts all the standardized criteria that fulfill factors loadings, Cronbach's alpha, CR, and AVE.

Table 2

Convergent validity

\begin{tabular}{|c|c|c|c|c|c|c|}
\hline Constructs & Items & Factor Loading & AVE & CR & Cronbach's Alpha & $\mathbf{R}^{2}$ \\
\hline \multirow{7}{*}{ Institute social responsibility (ISR) } & ISR1 & 0.765 & 0.680 & 0.937 & 0.922 & \\
\hline & ISR2 & 0.832 & & & & \\
\hline & ISR3 & 0.829 & & & & \\
\hline & ISR4 & 0.867 & & & & \\
\hline & ISR5 & 0.843 & & & & \\
\hline & ISR6 & 0.830 & & & & \\
\hline & ISR7 & 0.804 & & & & \\
\hline \multirow[t]{7}{*}{ Institute reputations (IR) } & IR1 & 0.817 & 0.641 & 0.926 & 0.907 & 0.457 \\
\hline & IR2 & 0.795 & & & & \\
\hline & IR3 & 0.848 & & & & \\
\hline & IR4 & 0.797 & & & & \\
\hline & IR5 & 0.781 & & & & \\
\hline & IR6 & 0.761 & & & & \\
\hline & IR7 & 0.805 & & & & \\
\hline \multirow[t]{17}{*}{ Student loyalty (SL) } & AL1 & 0.781 & 0.512 & 0.946 & 0.939 & 0.466 \\
\hline & AL2 & 0.831 & & & & \\
\hline & AL3 & 0.863 & & & & \\
\hline & AL4 & 0.853 & & & & \\
\hline & AL5 & 0.840 & & & & \\
\hline & AL6 & 0.831 & & & & \\
\hline & AL7 & 0.697 & & & & \\
\hline & AL8 & 0.660 & & & & \\
\hline & BL1 & 0.793 & & & & \\
\hline & BL2 & 0.833 & & & & \\
\hline & BL3 & 0.760 & & & & \\
\hline & BL4 & 0.667 & & & & \\
\hline & BL5 & 0.719 & & & & \\
\hline & BL6 & 0.630 & & & & \\
\hline & BL7 & 0.799 & & & & \\
\hline & BL8 & 0.819 & & & & \\
\hline & BL9 & 0.805 & & & & \\
\hline
\end{tabular}

\subsubsection{Discriminant Validity}

Discriminant validity refers to a situation where a researcher focuses that the two indicators should be different in terms of statistics (Rehman et al., 2019). Discriminant validity shows the level to which a variable, in actual, different from the other construct on the basis of some empirical evidence (Hair et al., 2014). Discriminant validity can be computed by using these two methods. First, compare the values of AVE with the squared correlation. Second, compare AVE square root with the correlations. This study used the second method to calculate Discriminant validity. The values of the upper diagonal in Discriminant validity table must be greater than the other values in similar row and columns (Fornell \& Larcker, 1981). Table 3 demonstrates that this study fulfills this criterion.

Table 3

Discriminant validity

\begin{tabular}{lccc}
\hline Variables & ISR & IR & SL \\
\hline Institute social responsibility (ISR) & $\mathbf{0 . 8 2 5}$ & & \\
Institute reputations (IR) & 0.676 & $\mathbf{0 . 8 0 1}$ & \\
Student loyalty (SL) & 0.540 & 0.673 & $\mathbf{0 . 7 1 6}$ \\
\hline
\end{tabular}

\subsection{Structural Model and Hypotheses Testing}

In this section, we examined the hypotheses proposed earlier by using SmartPLS 3.2.8 and two approaches of PLS algorithm and the bootstrapping have been used. Table 4 shows that the current research consists of 4 hypotheses, out of which 3 are direct hypotheses and 1 is indirect (mediating) hypothesis. 


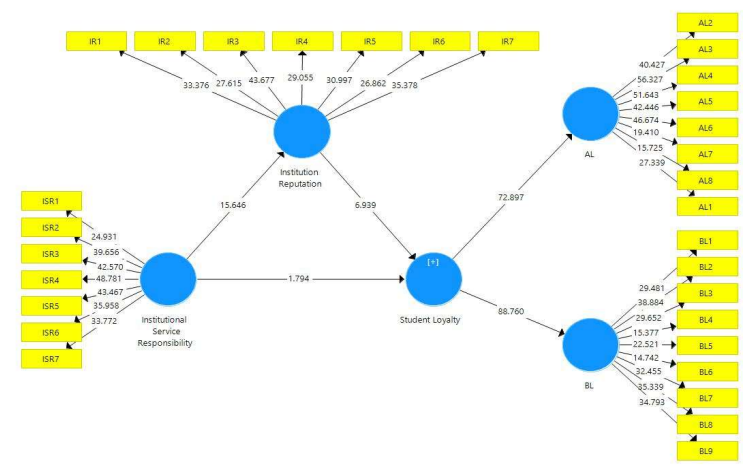

Fig. 3. Structural Model

Table 4

Direct and indirect relationships

\begin{tabular}{ccccccccc}
\hline Hypotheses & Paths & $\begin{array}{c}\text { Original } \\
\text { Sample }\end{array}$ & $\begin{array}{c}\text { Sample } \\
\text { Mean }\end{array}$ & $\begin{array}{c}\text { Std. } \\
\text { Dev. }\end{array}$ & T-Value & P-Value & Results \\
\hline $\mathbf{H}_{\mathbf{1}}$ & $\mathrm{ISR} \rightarrow \mathrm{SL}$ & 0.156 & 0.151 & 0.087 & 1.794 & 0.073 & Not Sig \\
$\mathbf{H}_{\mathbf{2}}$ & $\mathrm{ISR} \rightarrow \mathrm{IR}$ & 0.676 & 0.679 & 0.043 & 15.646 & 0.000 & $\mathrm{Sig}$ & $\mathrm{S}$ \\
$\mathbf{H}_{\mathbf{3}}$ & $\mathrm{ISR} \rightarrow \mathrm{IR} \rightarrow \mathrm{SL}$ & 0.383 & 0.390 & 0.069 & 5.578 & 0.000 & $\mathrm{Sig}$ & $\mathrm{Sig}$ \\
\hline $\mathbf{H}_{\mathbf{4}}$ & $\mathrm{IR} \rightarrow \mathrm{SL}$ & 0.567 & 0.572 & 0.082 & 6.939 & 0.000 & $\mathrm{Sig}$ \\
\hline
\end{tabular}

ISR=Institute's social responsibility; IR=Institute's reputation; $\mathrm{SL}=$ Student loyalty

\section{Results}

Table 4 demonstrates that institute social responsibility had no influence on student loyalty because $\beta=0.156, t=1.794$, and $p=0.073$ and $\mathrm{H}_{1}$ is not supported. Institute's social responsibility has a significant and positive influence on the institute's reputation $(\beta=0.676$, t-value $=15.646 \mathrm{p}=0.000)$ and thus $\mathrm{H}_{2}$ is supported. The institute reputation plays a vital role and explains the relationship between institutes social responsibility and student loyalty $(\beta=0.383, \mathrm{t}=5.578, \mathrm{P}$-value $=0.000)$ and supported our hypotheses $\mathrm{H}_{3}$. Finally, institute reputation significantly and positively enhances student loyalty $(\beta=0.572, t=6.939$, Pvalue $=0.000)$ and $\mathrm{H}_{4}$ is supported.

\subsection{The predictive relevance of study model}

Few researchers recommend the predictive relevance of the theoretical framework calculated with the help of R-square $\left(\mathrm{R}^{2}\right)$ and cross-validated redundancy $\left(\mathrm{Q}^{2}\right)$ (Geisser, 1974; Stone, 1974). Researchers compute $\mathrm{R}^{2}$ with the help of PLS algorithm in the SmartPLS tool and it shows the strength of the theoretical model on how well all the exogenous variables explained the endogenous construct (Rehman et al., 2019). Table 5 demonstrates that $45.7 \%$ institute reputation explained by the institute social responsibility and $46.6 \%$ student loyalty were explained by institutes responsibility and institutes reputation. Cohen (1988) recommended that the $\mathrm{R}^{2}$ value within the range of 0.02 to 0.13 is considered weak, 0.13 to 0.26 is considered moderate, and $\mathrm{R}^{2}$ value higher than 0.26 is considered substantial. This study shows that the institute reputation and student loyalty were considered substantial. Cross-validated $\left(\mathrm{Q}^{2}\right)$ redundancy was computed by using the blindfolding technique of the SmartPLS to determine the quality of the theoretical model. Few of the past studies recommended that the value of $\mathrm{Q}^{2}$ must be greater than zero (Chin, 1998a; Henseler et al., 2009). Table 5 demonstrates the $\mathrm{Q}^{2}$ value for institute reputation is 0.272 and for student loyalty is 0.220 . Therefore, this study fulfills the above-mentioned criterion regarding $\mathrm{Q}^{2}$.

\section{Table 5}

The Predictive relevance of study model

\begin{tabular}{lcc}
\hline Total & $\mathbf{R}^{\mathbf{2}}$ & $\mathbf{Q}^{\mathbf{2}}$ \\
\hline Institute reputation & 0.457 & 0.272 \\
Student loyalty & 0.466 & 0.220 \\
\hline
\end{tabular}




\section{Discussion and Conclusion}

The purpose of this research was to determine the mediating effect of institute reputation between the institute social responsibility and student loyalty. The results have revealed that institutes social responsibility had no direct influence on student loyalty. The results are in line with Liu and Ji (2010) who stated that social responsibility had no direct influence on customer loyalty. Institute's social responsibility has maintained a significant positive influence on the institute reputation and the result supported our hypotheses $\mathrm{H}_{2}$. The results are similar to Baraibar-Diez and Sotorrío (2018) and Benitez et al. (2017) who reported that social responsibility significantly enhanced reputation. Institute reputation, in our survey, significantly mediated between institutes social responsibility and student loyalty. This has shown that institutes reputation plays a remarkable role for HEIs to enhance student loyalty and management of institutes should take actions to enhance educational institute reputation. Institute reputation has maintained a significant and positive influence on student loyalty and supported our last hypothesis. The results are in line with Nuraryo et al. (2018). This study has elucidated that institutes social responsibility had a direct and positive influence on the institute reputation. Institutes social responsibility indirectly influenced student loyalty thru the mediating role of institute reputation in the Pakistani private HEIs. Besides, this study also confirmed the signaling theory and strategic enrolment management theory. Moreover, these factors supported the private HEIs leaders to emphasize on building a long term relationship among educational institutes and students. Thus, private HEIs financials rely on the new admissions and student enrolments are increased by the student loyalty (Massoud \& Ayoubi, 2018). Student loyalty is highly in favor of HEIs because it strongly builds relationship with universities, even though it forces to the student to stay connected after the completion of graduation (Giner, \& Peralt Rillo, 2016). Thus, building a strong relationship among private HEIs and students is possible thru student loyalty and is significantly influenced by the institute social responsibility and institute reputation.

\section{Limitations and suggestions}

The current study is entirely conducted in the Pakistani HEIs and the results of the current research contributes significantly to the institute social responsibility, institute reputation, and student loyalty. However, the results of the present study can be generalized to the rest of private HEIs of other provinces and may not be generalized all over the world because it varies country to country accordingly. The study was specified only for the private HEIs of the Punjab province and for the future studies we can consider other province's private universities or we can consider public HEIs of Pakistan. Particularly, researcher target the postgraduate students under the business educations discipline for data collection, for that purpose, researchers can consider other discipline's students for their future studies. Hence, there is a need to study this theoretical framework in other developing and developed countries. Furthermore, our focus was only on the institute social responsibility, institute reputation, and student loyalty only and researchers can add some other constructs to determine student loyalty.

\section{References}

Abubakar, M. M., \& Mokhtar, S. S. M. (2015). Modeling the effects of relational constructs on student satisfaction and loyalty to university. Journal of Marketing and HR, 1, 41-54.

Afthanorhan, W. (2013). A comparison of partial least square structural equation modeling (PLS-SEM) and covariance based structural equation modeling (CB-SEM) for confirmatory factor analysis. International Journal of Engineering Science and Innovative Technology, 2(5), 198-205.

Ali, F., Kim, W. G., Li, J., \& Jeon, H.-M. (2018). Make it delightful: Customers' experience, satisfaction and loyalty in Malaysian theme parks. Journal of Destination Marketing \& Management, 7, 1-11.

Ali, F., Zhou, Y., Hussain, K., Nair, P. K., \& Ragavan, N. A. (2016). Does higher education service quality effect student satisfaction, image and loyalty? A study of international students in Malaysian public universities. Quality Assurance in Education, 24(1), 70-94.

Ali, I., \& Zia, M. (2011). Corporate reputation influences consumer satisfaction and loyalty: evidence from cellular industry of Pakistan. Paper presented at the International Conference on Challenges for Knowledge Society, held on. 
Amiri, E., Ranjbar, M., \& Amiri, N. (2015). Corporate social responsibility in higher education. Paper presented at the Annals of International Conference on Humanities, Literature and Management, Dubai.

Anderson, R. E., \& Srinivasan, S. S. (2003). E-satisfaction and e-loyalty: A contingency framework. Psychology \& Marketing, 20(2), 123-138.

Annamdevula, S., \& Bellamkonda, R. S. (2016). Effect of student perceived service quality on student satisfaction, loyalty and motivation in Indian universities: Development of HiEduQual. Journal of Modelling in Management, 11(2), 488-517.

Baker, R. W. (2005). Capitalism's Achilles heel: Dirty money and how to renew the free-market system: John Wiley \& Sons.

Balabanis, G., Reynolds, N., \& Simintiras, A. (2006). Bases of e-store loyalty: Perceived switching barriers and satisfaction. Journal of Business Research, 59(2), 214-224.

Baraibar-Diez, E., \& Sotorrío, L. L. (2018). The mediating effect of transparency in the relationship between corporate social responsibility and corporate reputation. Revista Brasileira de Gestão de Negócios, 20(1), 521.

Benitez, J., Ruiz, L., Llorens, J., \& Castillo, A. (2017). Corporate social responsibility, employer reputation, and social media capability: an empirical investigation, 950-967.

Berger, K. A., \& Wallingford, H. P. (1997). Developing advertising and promotion strategies for higher education. Journal of Marketing for Higher Education, 7(4), 61-72.

Bromley, D. (2002). Comparing corporate reputations: league tables, quotients, benchmarks, or case studies? Corporate reputation review, 5(1), 35-50.

Caruana, A. (2002). Service loyalty: The effects of service quality and the mediating role of customer satisfaction. European Journal of Marketing, 36(7/8), 811-828.

Casidy, R., \& Wymer, W. (2016). A risk worth taking: Perceived risk as moderator of satisfaction, loyalty, and willingness-to-pay premium price. Journal of Retailing and Consumer Services, 32, 189-197.

Cha, M.-K., Yi, Y., \& Bagozzi, R. P. (2016). Effects of customer participation in corporate social responsibility (CSR) programs on the CSR-brand fit and brand loyalty. Cornell Hospitality Quarterly, 57(3), 235-249.

Chatman, J. A. (1989). Improving interactional organizational research: A model of person-organization fit. Academy of Management review, 14(3), 333-349.

Chin, W. W. (1998a). Commentary: Issues and opinion on structural equation modeling. MIS Quarterly, 22(1), 716.

Chin, W. W. (1998b). The partial least squares approach to structural equation modeling. Modern methods for business research, 295(2), 295-336.

Choi, B., \& La, S. (2013). The impact of corporate social responsibility (CSR) and customer trust on the restoration of loyalty after service failure and recovery. Journal of Services Marketing, 27(3), 223-233.

Cohen, J. (1988). Statistical power analysis for the behavioral sciences: Routledge.

Clemes, M., A. Cohen, D., \& Wang, Y. (2013). Understanding Chinese university students' experiences: an empirical analysis. Asia Pacific Journal of Marketing and Logistics, 25(3), 391-427.

Den Hond, F., Rehbein, K. A., de Bakker, F. G., \& Lankveld, H. K. v. (2014). Playing on two chessboards: Reputation effects between corporate social responsibility (CSR) and corporate political activity (CPA). Journal of Management Studies, 51(5), 790-813.

Dolence, M. G. (1993). Strategic Enrollment Management: A Primer for Campus Administrators.

Fatima, M., \& Khero, M. (2019). Factors Impacting the Student's Loyalty: An Empirical Investigation of Higher Education Sector In Pakistan. International Journal of Entrepreneurial Research, 1(2), 1-7.

Fisher, A. (2001). Winning the battle for customers. Journal of Financial Services Marketing, 6(1), 77-83.

Fombrun, C. J. (1996). Reputation: Realizing value from the corporate image. Harvard Business School Press, Boston, MA.

Fombrun, C. J., \& Shanley, M. (1990). What's in a name? Reputation building and corporate strategy. Academy of management journal, 33(2), 233-258.

Fombrun, C. J., Van Riel, C. B., \& Van Riel, C. (2004). Fame \& fortune: How successful companies build winning reputations: FT Press.

Fornell, C., \& Larcker, D. F. (1981). Evaluating structural equation models with unobservable variables and measurement error. Journal of marketing Research, 18(1), 39-50.

Fung, A. S. K., Southcott, J., \& Siu, F. L. (2017). Exploring mature-aged students' motives for doctoral study and their challenges: A cross border research collaboration. International Journal of Doctoral Studies, 12(1), 175195.

Geisser, S. (1974). A predictive approach to the random effect model. Biometrika, 61(1), 101-107. 
Gibbs, P., \& Knapp, M. (2012). Marketing higher and further education: An educator's guide to promoting courses, departments and institutions: Routledge.

Goosen, R. (2009). Universities and corporate social responsibility: A competitive advantage. Sustainability Blog.

Hair, J., Money, A., Samouel, P., \& Page, M. (2007). Research Methods for Business, UK Edition: John Wiley and Sons Ltd, West Sussex England.

Hair, J. F., Black, W., Babin, B., \& Anderson, R. (2010). Multivariate data analysis. Vectors, 8(2), 125-136.

Hair, J. F., Hult, G. T. M., Ringle, C., \& Sarstedt, M. (2014). A primer on partial least squares structural equation modeling (PLS-SEM). Thousand Oaks: Sage Publications.

Hair Jr, J. F., Hult, G. T. M., Ringle, C., \& Sarstedt, M. (2013). A primer on partial least squares structural equation modeling (PLS-SEM). Thousand Oaks, CA.: Sage Publications.

Hayduk, L. A., \& Littvay, L. (2012). Should researchers use single indicators, best indicators, or multiple indicators in structural equation models? BMC medical research methodology, 12(1), 159.

Helen, W. S. M. (2011). Building relationship between education institutions and students: Student loyalty in selffinanced tertiary education. IBIMA Business Review.

Helgesen, Ø. (2008). Marketing for higher education: A relationship marketing approach. Journal of Marketing for Higher Education, 18(1), 50-78.

Helm, S. (2005). Academic Research Designing a Formative Measure for Corporate Reputation. Corporate Reputation Review, 8(2), 95-109.

Hennig-Thurau, T., Langer, M. F., \& Hansen, U. (2001). Modeling and managing student loyalty: An approach based on the concept of relationship quality. Journal of service research, 3(4), 331-344.

Henseler, J., Ringle, C. M., \& Sinkovics, R. R. (2009). The use of partial least squares path modeling in international marketing New challenges to international marketing (pp. 277-319): Emerald Group Publishing Limited.

Heo, C. Y., \& Lee, S. (2016). Examination of student loyalty in tourism and hospitality programs: A comparison between the United States and Hong Kong. Journal of Hospitality, Leisure, Sport \& Tourism Education, 18, 69-80.

Hossler, D., \& Kalsbeek, D. (2013). Enrollment management and managing enrollments: Revisiting the context for institutional strategy. Strategic Enrollment Management Quarterly, 1(1), 5-25.

Hossler, D., Ziskin, M., Gross, J. P., Kim, S., \& Cekic, O. (2009). Student aid and its role in encouraging persistence Higher education: Handbook of theory and research (pp. 389-425): Springer.

Ipate, D. M., \& Parvu, I. (2011). Management-The Most Valuable Intangible Asset. Journal of Academic Research in Economics, 3(11), 300-308.

Jacoby, J., \& Kyner, D. B. (1973). Brand loyalty vs. repeat purchasing behavior. Journal of Marketing Research, 10(1), 1-9.

Jaiswal, A. K., \& Lemmink, J. G. A. M. (2017). Investigating a comparative evaluation approach in explaining loyalty. Marketing Intelligence \& Planning, 35(7), 937-954.

Jones, T. O., \& Sasser, W. E. (1995). Why satisfied customers defect. Harvard Business Review, 73(6), 88.

Krejcie, R. V., \& Morgan, D. W. (1970). Determining sample size for research activities. Educational and Psychological Measurement, 30(3), 607-610.

Lange, T. (2016). The Role of Relationship Marketing and SOAR in University Recruiting and Retention: Lawrence Technological University.

Liengjindathaworn, S., Saenchaiyathon, K., \& Hawat, P. (2015). Effect of corporate reputation to brand loyalty of banks in Thailand. International Business Management, 9(1), 134-138.

Liu, Y., \& Ji, H. (2010). A study on the perceived CSR and customer loyalty based on dairy market in China. Paper presented at the 2010 7th International Conference on Service Systems and Service Management.

Majeed, S., Aziz, T., \& Saleem, S. (2015). The effect of corporate governance elements on corporate social responsibility (CSR) disclosure: An empirical evidence from listed companies at KSE Pakistan. International Journal of Financial Studies, 3(4), 530-556.

Massoud, H., \& Ayoubi, R. M. (2018). Do flexible admission systems affect student enrollment? Evidence from UK universities. Journal of Marketing for Higher Education, 29(1), 1-18.

McNay, C. M. R. (2017). Empowering Enrollment Management Professionals to Achieve Enrollment Goals in Catholic Secondary Schools: A Qualitative Study of Leadership. California Lutheran University.

Moore, D., \& Bowden-Everson, J. L.-H. (2012). An appealing connection-the role of relationship marketing in the attraction and retention of students in an australian tertiary context. Asian Social Science, 8(14), 65-80.

Mukasa, K. D., Lim, H., \& Kim, K. (2015). How do corporate social responsibility activities influence corporate reputation? Evidence from Korean firms. Journal of Applied Business Research, 31(2), 383. 
Nunnally, J. C. (1978). Psychometric theory (Vol. 226): McGraw-Hill New York.

Nuraryo, I., Sumartias, S., \& Rahmat, H. U. A. A. (2018). The influence of corporate university identity on student retention with corporate reputation and student satisfaction as mediating variable: The case of a Jakarta business school. The Social Sciences, 13(8).

Nyadzayo, M. W., \& Khajehzadeh, S. (2016). The antecedents of customer loyalty: A moderated mediation model of customer relationship management quality and brand image. Journal of Retailing and Consumer Services, $30,262-270$.

Oliver, R. L. (1999). Whence consumer loyalty? Journal of marketing, 63(4_supp11), 33-44.

Parasuraman, A., Zeithaml, V. A., \& Berry, L. L. (1985). A conceptual model of service quality and its implications for future research. Journal of marketing, 49(4), 41-50.

Ram, J., \& Wu, M.-L. (2016). A fresh look at the role of switching cost in influencing customer loyalty: Empirical investigation using structural equation modelling analysis. Asia Pacific Journal of Marketing and Logistics, 28(4), 616-633.

Rehman, S.-u., Bhatti, A., \& Chaudhry, N. I. (2019). Mediating effect of innovative culture and organizational learning between leadership styles at third-order and organizational performance in Malaysian SMEs. Journal of Global Entrepreneurship Research, 9(1), 36.

Rehman, S.-u., Mohamed, R., \& Ayoup, H. (2019). The mediating role of organizational capabilities between organizational performance and its determinants. Journal of Global Entrepreneurship Research, 9(1), 30.

Ribbink, D., Van Riel, A. C., Liljander, V., \& Streukens, S. (2004). Comfort your online customer: quality, trust and loyalty on the internet. Managing Service Quality: An International Journal, 14(6), 446-456.

Salkind, N. (2012). Exploring research.. Hoboken: NJ: Pearson Education.

Sandberg, K. (2002). Kicking the tires of corporate reputation. Harvard Management Communication Letter, 5(1), 3-4.

Sevier, R. A. (1994). Image Is Everything--Strategies for Measuring, Changing, and Maintaining Your Institution's Image. College and University, 69(2), 60-75.

Shin, Y., \& Thai, V. V. (2015). The impact of corporate social responsibility on customer satisfaction, relationship maintenance and loyalty in the shipping industry. Corporate Social Responsibility and Environmental Management, 22(6), 381-392.

Skudiene, V., \& Auruskeviciene, V. (2012). The contribution of corporate social responsibility to internal employee motivation. Baltic Journal of Management, 7(1), 49-67.

Sok Kuan Fung, A., Southcott, J., \& L. C. Siu, F. (2017). Exploring Mature-Aged Students' Motives for Doctoral Study and their Challenges: A Cross Border Research Collaboration. International Journal of Doctoral Studies, 12 (January), 175-195. https://doi.org/10.28945/3790

Stiglitz, J. E. (1975). The theory of" screening," education, and the distribution of income. The American Economic Review, 65(3), 283-300.

Stone, M. (1974). Cross-validatory choice and assessment of statistical predictions. Journal of the Royal Statistical Society: Series B (Methodological), 36(2), 111-133.

Tingchi Liu, M., Anthony Wong, I., Rongwei, C., \& Tseng, T.-H. (2014). Do perceived CSR initiatives enhance customer preference and loyalty in casinos? International Journal of Contemporary Hospitality Management, 26(7), 1024-1045.

Turban, D. B., \& Greening, D. W. (1997). Corporate social performance and organizational attractiveness to prospective employees. Academy of management journal, 40(3), 658-672.

Turker, D. (2009). Measuring Corporate Social Responsibility: A Scale Development Study. Journal of Business Ethics, 85(4), 411-427. https://doi.org/10.1007/s10551-008-9780-6

Yeo, R. K., \& Marquardt, M. J. (2011). Through a different lens: bridging the expectation-perception (quality) divide in higher education. Asia Pacific Journal of Education, 31(4), 379-405.

Youness, H. R. (2012). Social responsibility of the Lebanese private universities: A qualitative study of Notre Dame University using document analysis of publicly available data: Saint Louis University.

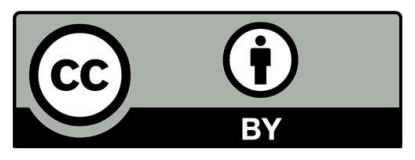

(C) 2019 by the authors; licensee Growing Science, Canada. This is an open access article distributed under the terms and conditions of the Creative Commons Attribution (CCBY) license (http://creativecommons.org/licenses/by/4.0/). 